\title{
Autosomal dominant Kenny-Caffey syndrome
}

INSERM

\section{Source}

INSERM. (1999). Orphanet: an online rare disease and orphan drug data base. Autosomal dominant Kenny-Caffey syndrome. ORPHA:93325

A rare, primary bone dysplasia characterized by severe growth retardation, short stature, cortical thickening and medullary stenosis of long bones, delayed closure of the anterior fontanelle, absent diploic space in the skull bones, prominent forehead, macrocephaly, dental anomalies, eye problems (hypermetropia and pseudopapilledema), and hypocalcemia due to hypoparathyroidism, sometimes resulting in convulsions. Intelligence is normal. 